\section{Peran mediasi self-efficacy pada work engagement dan perceived organizational support}

\author{
Devina Andriany ${ }^{1}$ dan IJK Sito Meiyanto ${ }^{2}$
}

\section{(4) Cognicia \\ p-ISSN 2746-8976; e-ISSN 2685-8428 ejournal.umm.ac.id/index.php/cognicia 2021, Vol 9(2):130-136 \\ DOI:10.22219/cognicia.v9i2.18265 (C)The Author(s) 2021 \\ ()(ㅇ)( 4.0 International license}

\author{
Devina Andriany' dan IJK Sito Meiyanto ${ }^{2}$
}

\begin{abstract}
Excellent human resources in the organization are seen as the principal capital for the company to improve the company's role, function, and competitiveness in facing developments and changes both internally and externally. Companies with high-stress levels need superior employees that motivated, passionate about work and loyal to the organization. These needs can refer to the characteristics of employees who are engaged with their work. However, there are still many dynamics of psychological constructs that have not been revealed that can increase work engagement. The purpose of this study was to determine whether self-efficacy can be a mediator on the effect of perceived organizational support (POS) on work engagement. The research was conducted through a survey method taken from 103 bank marketing employees. The collected data were analyzed through the structural equation model (SEM) and showed an indirect effect of perceived organizational support on work engagement $(a b=0.13$; $\leq 0.001)$. This result shows that self-efficacy partially mediates the relationship between perceived organizational support (POS) and work engagement and the research hypothesis is acceptable
\end{abstract}

\title{
Keywords
}

SEM, work engagement, perceived organizational support, self-efficacy

\section{Pendahuluan}

Kebutuhan akan SDM yang unggul menjadi kebutuhan utama untuk meningkatkan peran, fungsi serta daya saing perusahaan dalam mengantisipasi perkembangan kondisi dinamis ekonomi regional, nasional dan internasional. Kebutuhan tersebut dapat merujuk pada ciri-ciri karyawan yang engaged dengan pekerjaannya, yaitu karyawan dengan antusias dan berenergi tinggi, serta berkomitmen dengan pekerjaan mereka (Innanen et al., 2014) . Karena itu menumbuhkan work engagement karyawan menjadi penting sebagai modal dari organisasi (Caesens \& Stinglhamber, 2014) dan sebagai kunci potensial untuk keunggulan kompetitif perusahaan (van Tuin et al., 2020). Terutama semenjak tahun 2020 pentingnya memiliki tenaga kerja yang engaged akan menjadi lebih tangguh dan mampu mengatasi banyak tantangan yang datang dengan pandemi, keruntuhan ekonomi, dan kerusuhan sosial (Harter, 2021).

Konsep engagement telah berkembang dengan pembahasan yang lebih variatif selama satu dekade ini. Salah satunya dari Schaufeli et al. (2002) yang mengungkapkan bahwa work engagement sebagai keadaan aktif dan positif karyawan terkait dengan pekerjaannya yang ditandai dengan vigor (semangat), dedication (dedikasi), dan absorption (penyerapan). Daripada keadaan emosi tertentu sesaat, work engagement lebih mengacu pada kondisi afektif-kognitif yang berkelanjutan dan lebih dalam. Vigor ditandai oleh tingginya tingkat energi dan ketahanan mental saat bekerja, kemauan untuk mencurahkan usaha serta ketekunan dalam menghadapi kesulitan dalam bekerja. Dedication ditandai dengan kesungguhan untuk melibatkan diri dalam pekerjaan, yang diikuti rasa bermakna, antusiasme, inspirasi, kebanggaan dan tantangan. Absorption ditandai dengan keadaan sepenuhnya terkonsentrasi dan secara senang hati menikmati pekerjaannya sehingga waktu berlalu dengan cepat dan akan kesulitan memisahkan diri dari pekerjaan (Schaufeli \& Bakker, 2010).

Beberapa penelitian telah banyak berkembang selama dua dekade terakhir mengidentifikasi berbagai anteseden untuk work engagement seperti iklim kerja (Bakker et al., 2007), kepemimpinan (Carasco-Saul et al., 2015), dan motivasi (van Tuin et al., 2020). Melihat begitu banyaknya temuan yang menunjukkan pencapaian positif dari work engagement, para peneliti terus berusaha mengkaji konsep tersebut secara lebih mendalam untuk mengungkap faktor-faktor yang berkaitan dengan work

\footnotetext{
${ }^{1}$ Universitas Muhammadiyah Malang, Indonesia ${ }^{2}$ Universitas Gadjah Mada, Yogyakarta, Indonesia

Korespondensi:

Devina Andriany, Fakultas Psikologi Universitas Muhammadiyah Malang

Email: devina@umm.ac.id
} 
engagement. Salah satu faktor yang dapat menjadi anteseden ataupun prediktor dari work engagement adalah perceived organizational support (POS) (Alfatekha \& Budiono, 2021; Caesens \& Stinglhamber, 2014; Wollard \& Shuck, 2011). POS mencerminkan keyakinan umum yang dimiliki oleh karyawan bahwa organisasi menghargai kontribusi dan peduli tentang kesejahteraan mereka (Eisenberger \& Stinglhamber, 2011; Eisenberger et al., 1986). (Eisenberger et al., 1986), menyatakan bahwa hubungan karyawan dengan perusahaan adalah hubungan timbal balik sosial (social exchange relationship). Ketika perusahaan menawarkan imbalan dan kondisi kerja yang baik pada karyawan, mereka berharap muncul loyalitas dan peforma kerja yang lebih. Karyawan yang merasa mendapat dukungan dari perusahaan, akan memunculkan reciprocity norm, yaitu perilaku karyawan yang merasa wajib membalas perlakuan baik yang diterima dari perusahaan sebelumnya. Riggle et al. (2015) menunjukkan bahwa sangat penting untuk meningkatkan POS karyawan pemasaran karena dapat membantu mengurangi efek stres pada psikologis dan perilaku, meningkatkan kepercayaan kepada perusahaan, meningkatkan kepuasan kerja serta meningkatkan komitmen organisasi karyawan pemasaran.

Selain POS, salah satu faktor lain yang telah ditemukan mampu mempengaruhi work engagement dan memiliki korelasi positif untuk meningkatkan work engagement adalah self-efficacy (Consiglio et al., 2016; Caesens \& Stinglhamber, 2014; Salanova et al., 2011; Sweetman \& Luthans, 2010). Pengertian self-efficacy adalah penilaian seseorang tentang kemampuan mereka untuk mengatur dan melaksanakan program tindakan yang diperlukan untuk mencapai performa yang ditentukan (Bandura, 1997). Beberapa penelitian terhadap petugas pemasaran telah mengidentifikasi self-efficacy sebagai salah satu variabel paling penting pada kinerja petugas pemasaran (Bostjan et al., 2016; Yang et al., 2011). Bandura (1997) yang menyatakan bahwa semakin tinggi tingkat self-efficacy seseorang, semakin mereka menjadi mudah larut dalam tugas-tugasnya dan mereka akan cenderung memberikan usaha dan energi yang lebih dalam menyelesaikannya.

Pada penelitian Saks (2006) berdasarkan teori pertukaran sosial (social exchange theory) karyawan akan engaged sebagai respon sumber daya (POS) yang mereka terima dari organisasi. Lebih lanjut Eisenberger \& Stinglhamber (2011) mengungkapkan bahwa POS berpengaruh pada work engagement dengan cara meningkatkan minat intrinsik karyawan untuk tugas-tugas mereka dengan memperkuat self-efficacy. POS dapat meningkatkan selfefficacy dengan mempengaruhi beberapa sumber utama yang menurut Bandura (2012) berkontribusi kepada pembentukan self-efficacy individu (yaitu, mastery experience, vicarious experience, persuasi verbal serta keadaan emosional). semakin tinggi tingkat self-efficacy seseorang, semakin mereka menjadi mudah larut dalam tugastugasnya dan mereka akan cenderung memberikan usaha dan energi yang lebih dalam menyelesaikan tugas-tugas tersebut. individu dengan tingkat self-efficacy tinggi akan merasa mampu mengerjakan tugasnya dan merasa tertantang untuk menyelesaikannya. Dia akan cenderung menikmatinya dan merasa bersemangat serta sulit dipisahkan dengan pekerjaan tersebut (engaged). Berdasarkan pada uraian tersebut maka terbentuk kerangka penelitian seperti pada Gambar 1.

Berdasarkan bukti empiris dan teoritis yang telah diuraikan mengenai work engagement, POS, dan selfefficacy sebelumnya, maka peneliti mencoba untuk mendapatkan pemahaman yang lebih baik mengenai bagaimana karyawan engaged dengan pekerjaannya, melalui model penelitian yang bertujuan untuk mengkaji lebih dalam pengaruh pos terhadap work engagement dengan menggunakan self-efficacy sebagai variabel mediator.

Hipotesis yang diajukan dalam penelitian ini adalah self-efficacy mampu menjadi mediator terhadap pengaruh perceived organizational support (POS) terhadap work engagement.

\section{Metode}

Kerangka penelitian yang telah dipaparkan sebelumnya akan diuji menggunakan pendekatan kuantitatif yaitu pendekatan penelitian yang menekankan pada analisis data-data numerik (angka) yang diolah dengan menggunakan metode analisis (Azwar, 2007). Penelitian ini adalah penelitian dengan model survei, dengan memberikan deskripsi kuantitatif/angka dari tren, sikap, atau pendapat dari suatu populasi dengan mempelajari sampel dari populasi tersebut. Berdasarkan hasil sampel tersebut, peneliti membuat generalisasi atau kesimpulan atas populasi tersebut (Creswell, 2014).

\section{Subjek Penelitian}

Subjek dipilih dengan teknik purposive sampling yang memfokuskan pada karakteristik tertentu yang berfungsi untuk menjawab pertanyaan dari penelitian. Subyek dalam penelitian ini adalah 103 karyawan pada satu perusahaan bank yang ada baik di kantor pusat maupun kantor cabang dengan karakteristik antara lain karyawan bagian pemasaran baik kontrak maupun tetap yang telah memiliki masa kerja enam bulan dalam perusahaan dengan asumsi karyawan telah memahami dan beradaptasi dengan keadaan perusahaan. Berdasarkan data sebanyak $58.3 \%$ berjenis kelamin laki-laki, dengan rentang usia paling banyak berkisar antara 21-30 tahun (70.9\%) dan pendidikan terakhir mayoritas adalah lulusan S1 $(87.4 \%)$

\section{Variabel dan Instrumen Penelitian}

Pada penelitian ini terdapat tiga variable yang digunakan yaitu work engagement sebagai variable terikat, perceived organizational support sebagai variable bebas dan selfefficacy sebagai variable mediator.

Work engagement diukur menggunakan skala yang peneliti adaptasi dari Utrecht Work Engagement Scale (UWES) $(\alpha=0.946) 17$ oleh Schaufeli \& Bakker 


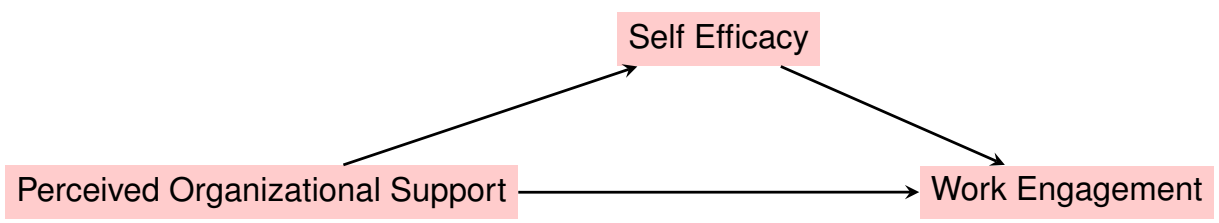

Gambar 1. Kerangka Penelitian

(2003). Skala ini terdiri dari 17 butir pernyataan dengan tujuh pilihan respon jawaban dari "tidak pernah" hingga respon "selalu". Penilaian respon pada skala ini adalah 0 (tidak pernah) hingga , 1 (hampir tidak pernah), 2 (jarang), 3 (kadang-kadang), 4 (sering), 5 (sangat sering), dan 6 (selalu). Semakin tinggi hasil dari penjumlahan keseluruhan aitem tersebut menunjukkan seseorang yang memiliki tingkat work engagement yang tinggi.

Alat ukur yang digunakan untuk mengukur POS adalah modifikasi skala POS $(\alpha=0.857)$ yang disusun oleh Septiyani (2012) berdasarkan aspek yang dikemukakan oleh Rhoades \& Eisenberger (2002). Skala ini terdiri dari 8 butir pernyataan dengan lima pilihan respon jawaban dari "sangat tidak setuju" hingga respon "sangat setuju". Penilaian respon pada skala ini adalah 0 (Sangat tidak setuju), 1 (Tidak setuju), 2 (Netral), 3 (Setuju), dan 4 (Sangat Setuju) untuk aitem favorable dan 4 (Sangat tidak setuju), 3 (Tidak setuju), 2 (Netral), 1 (Setuju), dan 0 (Sangat Setuju) untuk aitem unfavorable. Semakin tinggi hasil dari penjumlahan keseluruhan aitem tersebut menunjukkan seseorang yang memiliki tingkat POS yang tinggi.

Variabel self-efficacy diukur menggunakan skala selfefficacy ( $\alpha=0.868$ ) oleh Diniati (2015) yang telah dimodifikasi. Skala ini disusun berdasarkan berdasarkan aspek self-efficacy Bandura (1997). Skala ini terdiri dari 22 butir pernyataan dengan lima pilihan respon jawaban dari "sangat tidak sesuai" hingga respon "sangat sesuai". Penilaian respon pada skala ini adalah adalah 1 (sangat tidak sesuai), 2 (tidak sesuai), 3 (sesuai), dan 4 (sangat sesuai) untuk aitem favorable, dan 4 (sangat tidak sesuai), 3 (tidak sesuai), 2 (sesuai), dan 1 (sangat sesuai) untuk aitem unfavorable. Semakin tinggi hasil dari penjumlahan keseluruhan aitem tersebut menunjukkan seseorang yang memiliki tingkat self-efficacy yang tinggi.

\section{Prosedur dan Analisis Data Penelitian}

Peneliti menyebarkan skala penelitian secara langsung pada kantor-kantor cabang dari satu perusahaan bank di Indonesia. Setelah data terkumpul analisis digunakan untuk membuktikan hipotesis pada penelitian ini adalah dengan menggunakan structural equation model (SEM) karena SEM dapat menganalisis secara langsung dan komprehensif model persamaan yang memiliki variabel independen, mediator dan dependent, di mana masingmasing variabel memiliki beberapa aspek dan dalam bentuk variabel laten. Perhintungan dilakukan dengan menggunakan bantuan software AMOS.

\section{Hasil}

Data awal dari penelitian ini adalah sebanyak 105 karyawan bagian pemasaran di enam cabang perusahaan bank. Namun ketika proses uji normalitas data ditemukan dua data outlier sehingga total data yang digunakan untuk perhitungan menjadi 103 karyawan. Peneliti menerapkan Structural Equation Modeling (SEM) dengan menggunakan IBM AMOS 22, untuk mengkaji lebih lanjut model penelitian hipotesis

\section{Uji goodness-of-fit}

Goodness-of-fit mengukur kesesuaian input observasi sesungguhnya dengan perediksi dari model yang diajukan (Ghozali, 2014). Ada tiga jenis ukuran goodness-of-fit yaitu (1) absolute fit measures yang mengukur model fit secara keseluruhan (2) incremental fit measure ukuran untuk membandingkan model yang diajukan dengan model lain yang dispesifikasi oleh peneliti (3) parsimonious fit measures melakukan penyesuaian terhadap pengukuran fit untuk dapat diperbandingkan antar model dengan jumlah koefisien berbeda. Hasil komputasi dengan program AMOS untuk model SEM ini dihasilkan indeks goodnees of fit seperti pada Gambar 2.

Berdasarkan hasil model diagram di atas dapat diketahui bahwa seluruh asumsi goodness-of-fit telah terpenuhi dengan baik karena memenuhi persyaratan cut-off value, sehingga dapat disimpulkan bahwa model penelitian secara keseluruhan baik.

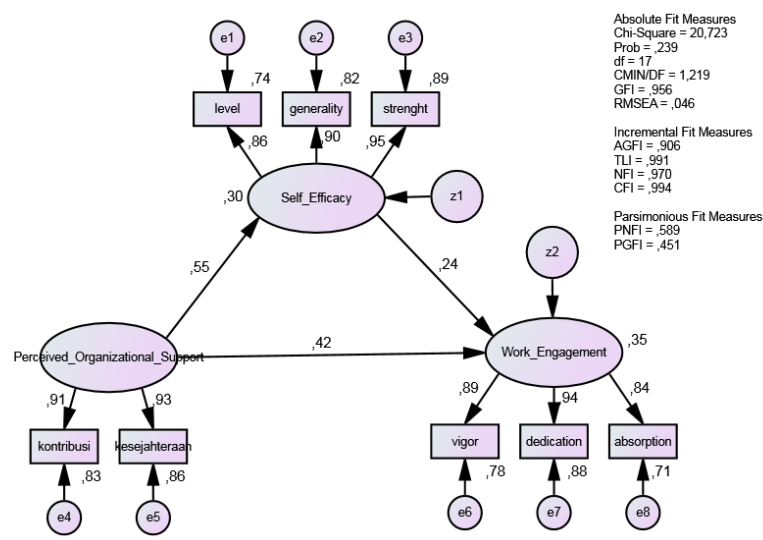

Gambar 2. Model Diagram 


\section{Uji Mediasi}

Pengujian efek mediasi berdasarkan pada pernyataan yang dikemukakan oleh Hair et al. (2010) bahwa untuk mengetahui efek mediasi pada penelitian harus memenuhi tiga aspek. Pertama, adalah memastikan bahwa ada pengaruh signifikan antar konstruk variabel.

Berdasarkan Tabel 1 dapat diketahui bahwa koefisien regresi (standardized regression) POS terhadap WE menunjukkan nilai sebesar $0.56(\mathrm{R} 2=0.31 ; \mathrm{p} \leq 0.001)$. Koefisien regresi POS terhadap SE sebesar 0.55 (R2 $=0.30 ; \mathrm{p} \leq 0.001)$. Koefisien regresi $\mathrm{SE}$ terhadap WE menunjukkan nilai sebesar $0.48 \quad(\mathrm{R} 2=0.23 ; \mathrm{p} \leq 0.001)$. Maka dapat disimpulkan bahwa POS memiliki pengaruh secara positif yang signifikan terhadap work engagement dengan sumbangan efektif sebesar $31 \%$, POS memiliki pengaruh secara positif yang signifikan terhadap selfefficacy dengan sumbangan efektif sebesar 30\%, dan selfefficacy memiliki pengaruh secara positif yang signifikan terhadap work engagement dengan sumbangan efektif sebesar $23 \%$.

Lebih lanjut pada Tabel 1 terdapat nilai indirect effect POS terhadap WE $(\mathrm{ab}=0.13)$. Nilai direct effects dari POS terhadap WE (c'=0.42) di mana lebih kecil dari nilai total effect POS terhadap WE (c=0.56). Hal ini menunjukkan bahwa pengaruh langsung POS terhadap work engagement menjadi berkurang ketika self-efficacy dimasukkan dalam model, sehingga dapat disimpulkan bahwa peran POS terhadap work engagement dimediasi secara parsial oleh variabel self-efficacy.

Berdasarkan hasil perhitungan model hipotesis pada penelitian ini kita dapat mengetahui bahwa nilai koefisien determinasi POS terhadap WE dengan SE sebagai mediator $(\mathrm{R} 2=0.351)$. Penelitian ini menjelaskan bahwa varians dari work engagement yang bisa dijelaskan oleh POS dan self-efficacy adalah sebesar 35.1\%. Hasil uji hipotesis yang telah dilakukan menunjukkan bahwa hipotesis penelitian yaitu self-efficacy mampu menjadi mediator terhadap pengaruh perceived organizational support (POS) terhadap work engagement dapat diterima.

\section{Diskusi}

Tujuan utama dalam penelitian ini adalah untuk mendapatkan pemahaman yang lebih baik mengenai mekanisme bagaimana karyawan engaged dengan pekerjaannya, melalui model penelitian yang bertujuan untuk mengkaji lebih dalam pengaruh pos terhadap work engagement dengan menggunakan self-efficacy sebagai variabel mediator. berdasarkan hasil perhitungan yang telah dilakukan, ditemukan bahwa self-efficacy mampu memediasi secara parsial pengaruh positif POS terhadap work engagement. berdasarkan hasil tersebut dapat disimpulkan bahwa hipotesis pada penelitian ini yaitu pos memiliki peran positif terhadap work engagement dengan self-efficacy sebagai mediator dapat diterima. penelitian ini menjelaskan varians dari self-efficacy sebesar $30 \%$ dan varians dari work engagement sebesar $35.1 \%$.
Hasil penelitian ini menunjukkan bahwa karyawan yang bekerja pada lingkungan kerja dimana perusahaan menghargai kontribusi dan peduli dengan kesejahteraan karyawannya, akan meningkatkan self-efficacy karyawan. self-efficacy yang tinggi mengarah pada tingkat work engagement yang tinggi. karyawan dengan self-efficacy yang tinggi menjadi mudah larut dalam tugas-tugasnya dan mereka akan cenderung memberikan usaha dan energy yang lebih dalam menyelesaikannya dan menuju pada keadaan engaged. karyawan dengan work engagement tinggi memiliki antusias, berenergi tinggi, serta berkomitmen dengan pekerjaan mereka. Jadi secara garis besar dapat disimpulkan bahwa semakin karyawan didukung dan dihargai oleh organisasi maka akan semakin tinggi keyakinan mereka akan kemampuannya dalam menyelesaikan tugasnya, mereka menjadi lebih larut dalam tugas-tugas mereka dan melakukan pekerjaan mereka dengan lebih semangat dan dedikasi (engaged).

Temuan ini sejalan dengan teori yang diungkapkan oleh Eisenberger \& Stinglhamber (2011) bahwa POS dapat berpengaruh pada work engagement dengan cara meningkatkan minat intrinsik karyawan untuk tugas-tugas mereka dengan cara memperkuat self-efficacy individu tersebut. ketika individu mendapatkan dukungan kuat dari perusahaan dan keyakinan dirinya akan berhasil dalam menyelesaikan tugas semakin meningkat dan keberhasilan akan lebih mungkin tercapai.

Hasil penelitian ini juga sejalan dengan beberapa penelitian sebelumnya yang menyebutkan bahwa POS memiliki pengaruh positif terhadap work engagement (Alfatekha \& Budiono, 2021; Caesens \& Stinglhamber, 2014; Wollard \& Shuck, 2011). Eisenberger \& Stinglhamber (2011) mengungkapkan bahwa karyawan dengan POS yang tinggi akan menemukan bahwa pekerjaannya menjadi pusat dalam hidupnya dan mereka akan lebih engaged dengan pekerjaannya. Karyawan yang didukung oleh organisasinya memperlihatkan kinerja yang lebih unggul dan melakukan tindakan sukarela dalam membantu organisasi memenuhi tujuannya.

Hubungan antara POS dan work engagement dapat dijelaskan dimana work engagement merupakan bentuk timbal balik yang diberikan karyawan terhadap dukungan yang telah diberikan kepada mereka agar dapat bekerja dengan lebih efektif. Hubungan antara karyawan dengan organisasi adalah hubungan timbal balik sosial (social exchange relationship) dimana organisasi akan menawarkan karyawan imbalan dan kondisi kerja yang baik, dengan harapan akan adanya loyalitas dan usaha kerja yang lebih dari karyawan. Ketika karyawan merasa telah didukung oleh organisasi, maka akan muncul reciprocity norm, dimana karyawan yang diperlakukan dengan baik, akan merasa wajib membalas perlakuan baik yang diterima dari organisasi. Karyawan dengan POS yang tinggi akan menemukan bahwa pekerjaannya menjadi pusat dalam hidupnya dan mereka akan lebih engaged dengan pekerjaannya (Eisenberger \& Stinglhamber, 2011; Eisenberger et al., 1986). 
Tabel 1. Besar Pengaruh Variabel Terstandar (standardized)

\begin{tabular}{|c|c|c|c|c|c|c|}
\hline & \multicolumn{2}{|c|}{ Total Effects $(c)$} & \multicolumn{2}{|c|}{ Direct Effects $\left(c^{\prime}\right)$} & \multicolumn{2}{|c|}{ Indirect Effects (ab) } \\
\hline & POS & Self-Efficacy & POS & Self-Efficacy & POS & Self-Efficacy \\
\hline Work Engagement & $.56^{\star \star *}$ & $.243^{* * *}$ & $.42^{* * *}$ & $.24^{* * *}$ & $.13^{\star \star \star}$ & $.00^{* * *}$ \\
\hline Self Efficacy & $.55^{\star \star \star}$ & $.00^{* * *}$ & $.55^{\star * *}$ & $.00^{* * *}$ & $.00^{* \star *}$ & $.00^{* * *}$ \\
\hline
\end{tabular}

$\mathrm{n}=103,{ }^{* * *} \mathrm{p}<.001$

Temuan pada penelitian ini juga mendukung penelitian yang menyebutkan bahwa POS memiliki pengaruh positif terhadap self-efficacy (Sihag \& Sarikwal, 2015). POS dapat meningkatkan self-efficacy dengan mempengaruhi beberapa sumber utama yang berkontribusi kepada pembentukan self-efficacy individu (mastery experience, vicarious experience, persuasi verbal serta keadaan emosional) (Eisenberger \& Stinglhamber, 2011). Sebagai contoh, dengan menilai kontribusi karyawan melalui feedback positif (persuasi verbal) pada performa kerja karyawan, POS akan mendorong karyawan untuk lebih aktif untuk ikut serta dalam peningkatan mastery experience yaitu kemampuan untuk menyelesaikan pekerjaan/tugas dengan sukses. Kesuksesan tersebut membangun kepercayaan yang kuat dalam self-efficacy individu. POS akan mampu meningkatkan self-efficacy dengan menciptakan keyakinan dan harapan bahwa organisasi mempedulikan kesejahteraan karyawannya dengan selalu siap memberikan bantuan dan sumberdaya materi ataupun emosional ketika diperlukan.

Hasil pada penelitian ini juga mendukung bukti empiris sebelumnya yang menyebutkan bahwa self-efficacy memiliki hubungan positif dengan work engagement (Consiglio et al., 2016; Caesens \& Stinglhamber, 2014; Salanova et al., 2011). Individu dengan tingkat self-efficacy tinggi, akan menginvestasikan lebih banyak usaha dan tekun dalam mencapai tujuannya. Hal ini didorong oleh kepercayaan bahwa mereka akan sukses di masa yang akan datang dan membuat mereka menjadi lebih gigih dan tekun mengarah pada keadaan engaged pada pekerjaannya (Salanova et al., 2011; Bandura, 1997).

Hubungan antara self-efficacy dan work engagement (Consiglio et al., 2016; Sweetman \& Luthans, 2010) dapat dijelaskan melalui hubungan sumber utama yang berpengaruh dalam pembentukan self-efficacy individu dengan work engagement pertama, mastery experience, karyawan yang pernah mengalami keberhasilan pada pekerjaannya cenderung memiliki rasa percaya diri lebih untuk menyelesaikan pekerjaan serupa di masa depan. Sumber utama ini dapat menjadi faktor penting untuk aspek absorption dan vigor. Karena karyawan berkompeten dalam pekerjaan tersebut maka dia akan menjadi lebih bersemangat dan mudah larut dalam keseluruhan pencapaian pekerjaan tersebut. Sumber utama lainnya yaitu vicarious experience dan persuasi verbal dapat mempengaruhi work engagement melalui dedication. Individu yang meningkat keyakinan dirinya, dengan melihat keberhasilan orang lain atau dorongan semangat dari sekitarnya, akan mampu mengidentifikasikan dirinya mampu menyelesaikan pekerjaan tersebut.

\section{Kesimpulan}

Hasil penelitian ini membuktikan bahwa hipotesis penelitian ini diterima yaitu self-efficacy mampu menjadi mediator terhadap pengaruh perceived organizational support (POS) terhadap work engagement. Hasil ini menunjukkan bahwa bahwa POS dapat mempengaruhi work engagement secara positif dengan meningkatkan minat intrinsik karyawan untuk tugas-tugas mereka salah satunya dengan cara meningkatkan self-efficacy karyawan. Sehingga dapat disimpulkan bahwa semakin karyawan didukung dan dihargai oleh organisasi maka akan semakin tinggi keyakinan mereka akan kemampuannya dalam menyelesaikan tugasnya, dan akhirnya mereka menjadi lebih larut dalam tugas-tugas mereka serta melakukan pekerjaan mereka dengan lebih semangat dan dedikasi (engaged).

Temuan pada penelitian ini menunjukkan implikasi bahwa untuk membuat karyawan lebih engaged dengan pekerjaannya, perusahaan perlu menjaga persepsi karyawan bahwa perusahaan akan membantu mereka ketika dalam penyelesaian tugas atau untuk membantu memenuhi kebutuhan mereka. Perusahaan dapat melakukan hal tersebut melalui kebijakan SDM berdasar pada prinsip sistem manajemen kinerja, dengan mendesain suatu sistem rewards berbasis pada performa yang dicapai oleh karyawan untuk memberikan feedback positif terhadap performa kerja karyawan yang tingi. Memberikan feedback positif terhadap kinerja yang tinggi, menimbulkan harapan bahwa akan ada konsekuensi yang menguntungkan bagi karyawan apabila mereka memberikan performa yang lebih. Namun perlu diperhatikan bahwa rewards harus didasarkan pada ekspektasi realistis dan tersedia pada bentuk skala agar lebih objektif.

Pada penelitian selanjutnya pemilihan subjek yang lebih variatif dapat dijadikan pertimbangan. Karyawan sales/pemasaran pada perusahaan bank yang berbeda dapat memperkaya dinamika dari data work engagement yang didapatkan. Selain itu ke depan bisa dipertimbangkan psychological capital (PsyCap) sebagai konstruk psikologi lain yang mungkin bisa memediasi antara POS dengan work engagement. Telah ada beberapa penelitian yang mendukung adanya hubungan positif antar POS dengan psycap begitu juga penelitian psycap dengan work engagement. Selain itu pada psycap terdapat salah satu 
karakteristik di dalamnya yaitu self-efficacy yang telah terbukti mampu memediasi hubungan POS dengan work engagement pada penelitian ini sehingga diharapkan karakteristik lain dalam psycap juga mampu menjadi mediator antara kedua variabel dalam penelitian ini.

\section{Referensi}

Alfatekha W, L. O., \& Budiono. (2021). The effect of perceived organizational support on work engagement through job crafting (study at general division employees of bank jatim head office surabaya). Journal of Business and Behavioural Entrepreneurship, 5(1), 109-126. https://doi.org/10.21009/ jobbe.005.1.07

Azwar, S. (2007). Metode Penelitian. Yogyakarta: Pustaka Pelajar

Bandura, A. (1997). Self-efficacy: The exercise of control. New York: Freeman.

Bandura, A. (2012), "On the functional properties of perceived self-efficacy revisited". Journal of Management, 38 (1), 944. doi: 10.1177/0149206311410606

Bakker, A. B., Hakanen, J. J., Demerouti, E., and Xanthopoulou, D. (2007). Job resources boost work engagement, particularly when job demands are high. J. Educ. Psychol. 99, 274-284. doi: 10.1037/0022-0663.99.2.274

Bostjan, A., Jasna, A. A., \& Marketta, A. H. (2016). Marketing self-efficacy and firm creation. Journal of Small Business and Enterprise Development, 23(1), 90-104. https://doi.org/10. 1108/JSBED-07-2015-0093

Caesens, G., \& Stinglhamber, F. (2014). The relationship between perceived organizational support and work engagement: The role of self-efficacy and its outcomes. Revue Européenne de Psychologie Appliquée/European Review of Applied Psychology, 64(5), 259-267. https://doi.org/10.1016/j.erap. 2014.08.002

Carasco-Saul, M., Kim, W., and Kim, T. (2015). Leadership and employee engagement. Hum. Resour. Dev. Rev. 14, 38-63. doi: 10.1177/1534484314560406

Consiglio, C., Borgogni, L., Di Tecco, C., \& Schaufeli, W. B. (2016). What makes employees engaged with their work? The role of self-efficacy and employee's perceptions of social context over time. Career Development International, 21(2), 125-143. https://doi.org/10.1108/CDI-03-2015-0045

Creswell, J. W. (2014). Research design: Qualitative, quantitative, and mixed methods approaches. (4th ed). California: SAGE Publications, Inc.

Diniati, M. D. (2015). Peran kepercayaan pada organisasi dan efikasi diri kerja terhadap job insecurity pada karyawan kontrak [Unpublished doctoral dissertation]. Fakultas Psikologi Universitas Gadjah Mada, Yogyakarta.

Eisenberger, R., Hungtington, R., Hutchison, S., \& Sowa, D. (1986). Perceived organizational support. Journal of Applied Psychology, 71, 500-507. http://classweb.uh.edu/eisenberger/wp-content/uploads/ sites/21/2015/04/22_Perceived_Organizational_Support.pdf

Eisenberger, R., \& Stinglhamber, F. (2011). Perceived organizational support: Fostering enthusiastic and productive employees. Washington, DC: American Psychological Association Books.

Hair, J. F., Black, W. C., Babin, B. J., \& Anderson, R. E. (2010). Multivariate Data Analysis: A Global Perspective (7th ed.). New Jersey: Prentice Hall.

Harter, J. (2021). U.S. employee engagement holds steady in first half of 2021. Retrieved August 26, 2021, from https://www.gallup.com/workplace/352949/employeeengagement-holds-steady-first-half-2021.aspx

Innanen, H., Tolvanen, A., \& Salmela-aro, K. (2014). Burnout , work engagement and workaholism among highly educated employees: Profiles, antecedents and outcomes. Burnout Research, 1(1), 38-49. doi.org/10.1016/j.burn.2014.04.001

Karatepe, O. M. (2015). Do personal resources mediate the effect of perceived organizational support on emotional exhaustion and job outcomes? International Journal of Contemporary Hospitality Management, 27(1), 4-26. doi: 10.1108/02656710210415703

Rhoades, L., \& Eisenberger, R. (2002). Perceived organizational support: A review of the literature. Journal of Applied Psychology, 87(4), 698-714. https://doi.org/10.1037/00219010.87.4.698

Riggle, R. J., Solomon, P., \& Artis, A. (2015). The impact of perceived organizational support on salesperson psychological and behavioral work outcomes. International Journal of Management Research and Business Stretegy, 4(1), 297-311. doi:10.1016/S0149-2063

Saks, A. (2006). Antecedents and consequences of employee engagement. Journal of Managerial Psychology, 21(7), 600-619. doi:10.1108/02683940610690169

Salanova, M., Llorens, S. and Schaufeli, W.B. (2011), “'Yes, I can, I feel, I just do it!' On gain cycles and spirals of efficacy beliefs, affect and engagement". Applied Psychology: An International Review, Vol. 60 No. 2, pp. 255-285. doi: 10.1111/j.1464-0597.2010.00435.x

Schaufeli, W. B., Martinez, I. M., Pinto, a. M., Salanova, M., \& Bakker, a. B. (2002). Burnout and engagement in university students: A Cross-National Study. Journal of Cross-Cultural Psychology, 33(5), 464-481. https://doi.org/ 10.1177/0022022102033005003

Schaufeli, W. B., \& Bakker, A. B. (2003). UWES: Utrecht work engagement scale preliminarty manual. Journal of Occupational Health Psychology, (November). Retrieved from http://www.beanmanaged.com/doc/pdf/arnoldbakker/ articles/articles_arnold_bakker_87.pdf.

Schaufeli, W. B., \& Bakker, A. B. (2010). Defining and measuring work engagement: Bringing clarity to the concept. In A. B. Bakker \& M. P. Leiter (Eds.), Work engagement a handbook of essential theory and research (pp. 10-24). New York: Psychology Press.

Septiyani, R. (2012). Hubungan antara emotional labour dan work engagement dengan dimoderatori oleh dukungan organisasi. Tesis yang tidak dipublikasikan. Fakultas Psikologi Universitas Gadjah Mada, Yogyakarta. 
Sihag, P., \& Sarikwal, L. (2015). Effect of perceived organizational support on psychological capital: A study of IT industries in Indian framework. EJBO-Electronic Journal of Business Ethics and Organization Studies, 20(2), 19-26. http://ejbo.jyu.fi

Sweetman, D., \& Luthans, F. (2010). The power of positive psychology: Psychological capital and work engagement. In A. B. Bakker, \& M. P. Leiter (Eds.), Work engagement: A handbook of essential theory and research (pp. 54-68). New York: Psychology Press

van Tuin, L., Schaufelt, W. B., van den Broeck, A., \& van Rhenen, W. (2020). A corporate purpose as an antecedent to employee motivation and work engagement. Frontiers in Psychology, 11(September). https://doi.org/10.3389/fpsyg.2020.572343
Wollard, K. K., \& Shuck, B. (2011). Antecedents to employee engagement: a structured review of the literature. Advances in Developing Human Resources, 13(4), 429-446. http://doi. org/10.1177/1523422311431220

Yang, B., Kim, Y., \& Mcfarland, R. G. (2011). Individual differences and sales performance: A distal-proximal mediation model of self-efficacy, conscientiousness and extraversion, Journal of Personal Selling \& Sales Management. XXXI(4), 371-381. doi:10.2753/PSS0885-3134310401 